\title{
IMPLEMENTASI UNDANG-UNDANG NO 14 TAHUN 2008 TENTANG KETERBUKAAN INFORMASI PUBLIK OLEH PEJABAT PENGELOLA INFORMASI DAN DOKUMENTASI (PPID) KEMKOMINFO
}

\author{
Diliana Ade Pembayun, Aryo Bimo Oktafianto, dan Syafiq Basri Assegaff \\ Sekolah Tinggi Ilmu Komunikasi London School of Public Relations Jakarta \\ Email : dilianaadepembayun@gmail.com \\ Aryobimo001@gmail.com \\ syafiqba18@gmail.com
}

\begin{abstract}
This research discusses about law No. 14 year 2008, the openness of public information implemented by the officers of the information and documentation Officer (PPID) Kemkominfo. The Act on public information disclosure aims to improve the management, service of information, and encourage public participation in the conduct of the State so as to realize the system of good governance. The purpose of this research is to describe how the Official information and documentation Manager (PPID) of the Ministry of communication and Informatics of carrying out the implementation of law No. 14 year 2008 about the openness of public information. The method used in this research is descriptive in nature with qualitative data collection techniques in the form of interviews with the informant Acting Manager of information and documentation. Data analysis techniques using models, Miles and Huberman that consists of data collection, data reduction, data display and verification, and assertion inference. Examination technique benefiting using triangulation of sources. The results of this research show the implementation ACT KIP done with through the six steps, namely: designating the PPID, build and make the system functional officials, pointing to information (public relations, archives, computer), providing information in the form (text, video, sound, infographics), providing information services in the form of front desk and website, as well as compiling daily, monthly and annual reports.
\end{abstract}

Keywords: Implementation, information disclosure, LAW number 14 year 2008

\section{A. PENDAhuluan}

Kementerian Komunikasi dan Informatika (Kemkominfo) merupakan mitra masyarakat yang pemnting artinya dalam membantu Pemerintah Indonesia untuk memahami setiap kebijakan yang diambil pemerintah. Dalam kinerjanya, Kemkominfo mengedepankan hubungan yang baik dengan masyarakat karena tugas mereka untuk menyelenggarakan urusan pemerintahan di bidang komunikasi dan informatika untuk membantu presiden dalam menyelenggarakan pemerintahan negara.

Sejak zaman reformasi, masyarakat sekarang semakin menuntut pemerintahan yang lebih transparan dan terbuka, sehingga mau tidak mau pemerintahan setelah reformasi itu berusaha menjalankan pemerintahan dengan lebih transparan dan akuntabel. Satu di antara langkah 
penting yang dilakukan pemerintah RI belakangan ini adalah munculnya Undang-Undang Republik Indonesia Nomor 14 Tahun 2008 tentang Keterbukaan Informasi Publik atau disingkat UU KIP yang salah satu tujuannya adalah meningkatkan pengelolaan dan pelayanan informasi di lingkungan Badan Publik.

Pengelolaan informasi publik merupakan salah satu upaya untuk mendorong partisipasi rakyat dan memajukan tujuan pemerintahan yang transparan, efektif, efesien, dan bertanggungjawab. Adanya UU No.14 tahun 2008 di Indonesia menjadi sarana dalam mengoptimalkan pengawasan publik dan segala sesuatu yang berakibat pada kepentingan publik. Informasi sendiri merupakan kebutuhan pokok setiap orang bagi pengembangan pribadi dan lingkungan sosialnya serta merupakan bagian penting bagi ketahanan nasional.

Berdasakan penjelasan dalam UU No.14 Tahun 2008 tentang Keterbukaan Informasi Publik atau UU KIP (Kementerian Komunikasi dan Informatika RI, 2008) merupakan landasan adanya transparasi informasi yang berada di badan publik. UU ini mengatur empat hal pokok di antaranya yaitu:

a. Hak setiap orang untuk memperoleh informasi;

b. Kewajiban badan publik menyediakan dan melayani permintaan informasi secara cepat, tepat waktu, proposional dan sederhana;

c. Informasi yang di kecualikan bersifat ketat dan terbatas;

d. Kewajiban badan publik untuk membenahi sistem dokumentasi dan pelayanan informasi.

Implementasi UU KIP ditubuh Kemkominfo dilakukan dengan pengembangan peraturan terkait pelaksaan keterbukaan informasi publik di lingkungannya. Peraturan Pemerintah RI No.61 Tahun 2010 tentang Pelaksanaan Keterbukaan Informasi Publik di lingkungan Kemkominfo merupakan peraturan yang dikeluarkan untuk mendukung UU KIP. Selanjutnya untuk mewujudkan pelayanan cepat, tepat, dan sederhana setiap badan publik menunjuk Pejabat Pengelola Informasi dan Dokumentasi (PPID) yang berwenang untuk membuat dan mengembangkan sistem penyediaan pelayanan keterbukaan informasi sesuai dengan UU KIP pasal 13 ayat 1 .

Secara struktural kedudukan PPID di kantor pusat Kementerian Komunikasi dan Informatika dilekatakan dengan divisi hubungan masyarakat dan dapat dibantu pejabat Kementerian Komunikasi dan Informatika yang berkedudukan di daerah. PPID adalah Pejabat ex-officio Kepala Pusat Informasi dan Humas Kementerian Komunikasi Dan Informatika. 
PPID Kemkominfo bertugas untuk merencanakan dan mengorganisasikan, melaksanakan, mengawasi, dan mengevaluasi pelaksanaan kegiatan pengelolaan dan pelayanan informasi di lingkungan Kementerian Komunikasi Dan Informatika. Dalam pelaksanaannya PPID dibantu oleh pejabat fungsional. Pejabat Fungsional Pengelola Informasi dan Dokumentasi (PFPID) memiliki kompetensi di bidang pengelolaan informasi dan dokumen serta pelaksanaan pelayanan informasi publik. PFPID ini terdiri dari arsiparis, pranata komputer, pranata humas, pustakawan, dan pejabat fungsional lainnya yang diperlukan.

Kegiatan humas merupakan suatu aktifitas dari fungsi strategi dan manajemen yang melakukan komunikasi untuk menciptakan suatu pemahaman yang sama dan bisa di terima oleh masyarakat. Dalam prosesnya, badan publik seharusnya bersifat terbuka, jujur dan memperhatikan hubungan yang baik dengan masyarakat. Seperti yang diungkapkan oleh (Aldily, 2017, p. 13) dalam bukunya 1001 Amazing Public Reation Ideas yang menjelaskan bahwa humas memiliki dua fungsi utama, salah satunya adalah sebagai a source of information (sumber informasi) yang tidak hanya bagi pihak eksternal saja melainkan sebagai sumber informasi bagi pihak internal. Kedudukan PPID yang melekat di bidang humas, dalam perannya memiliki kewajiban untuk memberikan pelayanan informasi demi terealisasinya tujuan UU KIP di Indonesia.

\section{B. TINJAUAN PUSTAKA}

\section{Model Public Relations}

Model Public Relations pertama kali diperkenalkan oleh James Grunig \& Hunt dalam buku Managing Public Relations (1984). Menurut Grunig \& Hunt di dalam buku Kriyantono (2014, p. 91) model ini dikatakan sebagai proses kegiatan public relations dalam menjalin hubungan dengan publik.

Grunig \& Hunt membagi keempat model ini berdasarkan empat dimensi utama, yaitu:

1. Arah komunikasi, menjelaskan bagaimana perilaku komunikasi antara organisasi dengan publik, apakah hanya bersifat menyebarkan informasi (one way) atau bersifat bertukar informasi (two way)

2. Tujuan, menjelaskan keseimbangan tujuan antara organisasi dan publik, yaitu posisi tidak seimbang/asymmetric (one-side dan advokasi kepentingan organisasi) dan posisi seimbang/symmetric antara organisasi dan publiknya (kolaborasi dan kerja sama). 
3. Saluran, membahas saluran-saluran komunikasi : interpersonal dan media.

4. Etis, hasil dari aktivitas public relations.

Terdapat empat model public relations. Keempat model tersebut ialah:

a. Model Press Agentry (Publisitas), dimana proses penyebaran informasi bergerak satu arah (one way communication) yaitu dari organisasi kepada publik. Model ini dapat dikatakan model utama yang muncul pada tahun 1850 hingga 1990. Pada dasarnya Press Agentry merupakan upaya praktisi Public Relations dalam menyebarkan informasi dengan melakukan publisitas atau promosi. Model ini banyak digunakan oleh Praktisi Public Relations dalam melakukan propaganda atau kampanye untuk tujuan publisitas media yang menguntungkan pihaknya.

b. Model Public Information. Model ini mulai diterapkan pada tahun 1900 hingga tahun 1920-an. Model ini bertujuan untuk membangun kepercayaan publik dengan memberikan informasi. Penyebaran informasi pada model ini berbeda dengan model Press Agentry yang hanya bertujuan untuk melakukan publisitas, namun penyebaran informasi dilakukan untuk memberikan informasi yang dibutuhkan oleh publik. Hanya saja informasi yang disampaikan bersifat untuk memberikan keuntungan bagi organisasi. Dengan kata lain ada pemilihan informasi yang dilakukan oleh organisasi sebelum diberikan kepada publik, sehingga organisasi mendapatkan kepercayaan publik.

c. Model Two-Way Asymmetric. Grunig \& Hunt mengganggap bahwa model two way asymmetric dan symmetric tergolong kedalam komunikasi dua arah. Komunikasi memiliki peran penting sebagai berkumpulnya informasi dan feed back dari publik untuk mengambil suatu keputusan. Model two way asymmetric lebih menekankan komunikasi sebagai alat untuk mempersuasi publik agar bertindak seperti apa yang diinginkan oleh organisasi.

d. Model Two-Way Symmetric. Grunig \& white berpendapat bahwa model two way symmetric berbeda dengan ketiga model sebelumnya yang hanya berupaya merubah perilaku publik tanpa dibarengi upaya perubahan pada organisasi. Model yang eksis ditahun 1960-an ini beranggapan bahwa perilaku komunikasi suatu organisasi maupun publik dapat berubah sebagai akibat adanya program komunikasi. Menurut Fakwes, Grunig \& Hunt, Harrison dan Wehmeier (dalam Kriyantono, 2014, p. 97) mengatakan bahwa model symmetric ini ideal karena mengutamakan dialog secara penuh dengan publiknya dan bertujuan fokus dalam membangun hubungan serta pemahaman bersama. Model ini menekankan prinsip "give and 
take" dimana organisasi dan publik mencapai suatu kesepakatan bersama. Seperti yang dikatakan oleh Grunig (dalam Ruliana, 2016, p. 195) bahwa model symmetric merupakan model yang mengarah kepada "telling the truth to public". Model komunikasi diterapkan untuk memfasilitasi apa yang diharapkan oleh publik bukan untuk mengidentifikasi pesan apa yang dapat digunakan untuk mempersuasi publik. Dengan kata lain, organisasi menganggap publik sebagai sumber dan penerima informasi, sehingga terjadi pertukaran informasi antara organisasi dan publik.

\section{Definisi Implementasi Kebijakan Publik}

Menurut Mazmanian dan Sebastiar (dalam Wahab, 2008, p. 184). Implementasi adalah pelaksanaan keputusan kebijakan dasar, biasanya dalam bentuk undang-undang, perintah, atau keputusan-keputusan eksekutif yang penting atau keputusan badan peradilan.

Kebijakan publik dapat berbentuk Undang-Undang atau Perda yang dapat diimplementasikan dalam penyelenggaraan negara, khususnya pada manajemen sektor publik (Nugroho, Public Policy, 2009, p. 495). Agar tujuan dari rumusan kebijakan publik dapat tercapai, maka kebijakan publik harus dapat diwujudkan dan diimplementasikan dengan baik oleh badan publik/badan pemerintah.

Sedangkan Edwards (dalam Winarno, 2011, p. 177) mendefinisikan implementasi kebijakan sebagai suatu tahap kebijakan publik, antara pembentukan kebijakan dan dampak yang akan ditimbulkan dari kebijakan tersebut bagi masyarakat.

Faktor-faktor yang memengaruhi implementasi telah dijelaskan pada teori implementasi dari Geogre C. Edwards (dalam Winarno, 2011, p. 177), yang antara lain adalah sebagai berikut.

\section{a. Komunikasi}

Petunjuk pelaksaanan tidak hanya harus dipahami, akan tetapi harus konsisten dan jelas.

Keberhasilan implementasi kebijakan mensyaratkan agar implementor mengetahui apa yang harus dilakukan. Apa yang menjadi tujuan dan sasaran kebijakan harus ditransmisikan kepada sasaran kelompok sehingga implementasi dapat benar-benar berjalan. Apabila tujuan dan sasaran suatu kebijakan tidak diketahui, maka kemungkinan akan terjadi resistensi dari kelompok yang disasar.

b. Sumber daya 
Walaupun isi kebijakan sudah dikomunikasikan secara jelas dan konsisten, tetapi apabila implementor kekurangan sumber daya untuk melaksanakannya, implementasi tidak akan berjalan efektif. Sumber daya terbagi menjadi dua, yakni sumber daya manusia (staff) dan sumber daya finansial (fasilitas). Sumber daya adalah faktor penting agar implementasi berjalan efektif.

c. Disposisi

Disposisi adalah atau kecenderungan-kecenderungan watak dan karakteristik yang dimiliki oleh implementor, seperti komitmen, kejujuran dan sifat demokratis. Apabila implementor memiliki disposisi yang baik, maka kebijakan akan dijalankan dengan baik seperti yang diinginkan oleh pembuat kebijakan. Sebaliknya, apabila disposisi implementor berbeda dengan pembuat kebijakan, maka implementasi tidak akan berjalan efektif.

d. Struktur Birokrasi

Struktur organisasi yang bertugas mengimplementasikan kebijakan memiliki pengaruh yang signifikan terhadap implementasi kebijakan. Salah satu aspek struktur yang penting adalah adanya standar prosedur operasi (standard operating procedurs) atau yang biasa disebut dengan SOP. SOP menjadi pedoman bagi setiap implementor dalam bertindak.

\section{Pengertian Keterbukaan Informasi Publik}

Menurut Kamus Besar Bahasa Indonesia (KBBI) keterbukaan adalah hal terbuka yang merupakan landasan utama dalam berkomunikasi.

Sedangkan informasi adalah "keterangan,pernyataan, gagasan, dan tanda-tanda yang mengandung nilai, makna,dan pesan, baik data, fakta maupun penjelasannya yang dapat dilihat, didengar, dan dibaca yang disajikan dalam berbagai kemasan dan format sesuai dengan perkembangan teknologi informasi dan komunikasi secara elektronik ataupun nonelektronik', (Kementerian Komunikasi dan Informatika RI, p. 3).

Informasi publik dapat diartikan sebagai "'informasi yang dihasilkan, disimpan, dikelola, dikirim dan/atau diterima oleh suatu badan publik yang berkaitan dengan penyelenggara dan penyelenggaraan negara dan/atau penyelenggara dan penyelenggaraan badan publik lainnya yang sesuai dengan Undang-Undang ini serta informasi lain yang berkaitan dengan kepentingan publik', (Pasal 1 UU No 14 Tahun 2008 Tentang Keterbukaan Informasi Publik). 
Keterbukaan informasi lahir berdasarakan adanya tuntutan demokrasi serta transparansi pasca reformasi tahun 1998. Adanya hak masyarakat untuk mengetahui dan mendapatkan informasi pemerintahan secara terbuka dan transparan yang kemudian mengantarkan pemerintah untuk menetapkan UU No.14 Tahun 2008 Tentang Keterbukaan Informasi Publik sebagai payung hukum. Tujuan dari keterbukaan informasi publik sendiri adalah untuk mewujudkan pelaksanaan tata kelola perusahaan yang baik melalui prinsip transparansi, akuntabilitas, pertanggung jawaban, kemandirian dan kewajaran serta mendorong partisipasi aktif masyarakat dalam proses pengambilan kebijakan publik (Kementerian Komunikasi dan Informatika RI, 2017).

Berdasarkan beberapa pengertian diatas, dapat ditarik kesimpulan bahwa Keterbukaan Informasi Publik merupakan suatu kebijakan negara yang harus diimplementasikan oleh badan publik dengan menyediakan informasi secara transparan kepada masyarakat sesuai dengan yang dituangkan dalam Undang-Undang No.14 Tahun 2008 Tentang Keterbukaan Informasi Publik.

\section{Undang-Undang No.14 Tahun 2008 Tentang Keterbukaan Informasi Publik}

Undang-Undang Nomor 14 Tahun 2008 merupakan salah satu program legislasi inisiatif Dewan Perwakilan Rakyat (DPR) pada masa bakti 1999-2004.

Undang Undang Keterbukaan Informasi Publik (KIP) awalnya bernama Kebebasan Mendapat Informasi Publik(KMIP) sudah dibahas sejak tahun 1999. Sejak melewati proses selama Sembilan tahun, karena tuntutan adanya tata kelola pemerintahaan yang baik (Good Governance) melalui prinsip akuntabilitas, transparan, dan partisipasi masyarakat dalam setiap proses terjadinya pengambilan keputusan suatu kebijakan publik.

UU No.14 Tahun 2008 disahkan oleh DPR pada tanggal 3 April 2008, dan diundangkan pada tanggal 30 April 2008. Melewati dua tahun masa persiapan pelaksanaan keterbukaan informasi publik, mulai tanggal 30 April 2010, UU No.14 tahun 2008 Tentang Keterbukaan Informasi Publik mulai efektif diberlakukan di seluruh Indonesia (Seketariat Jenderal dan Bidang Keahlian DPR RI, 2018).

Undang-Undang No.14 Tahun 2008 Tentang Keterbukaan Informasi Publik memuat 14 bab dan 64 pasal. Keseluruhan Undang-Undang tersebut tidak hanya mengatur hak publik untuk mengakses informasi tersebut secara bebas dan terbuka, namun juga mengatur tentang kewajiban badan publik untuk menyediakan akses informasi secara mudah dan transparan. 
Dapat disimpulkan bahwa Undang-Undang No.14 Tahun 2008 Tentang keterbukaan Informasi Publik merupakan suatu kebijakan resmi yang mengatur kewajiban, tugas dan wewenang badan publik dalam mengimplementasikan Keterbukaan Informasi Publik.

\section{Pejabat Pengelola Informasi dan Dokumentasi}

Pejabat Pengelola Informasi dan Dokumentasi atau yang disebut juga PPID merupakan pejabat yang ditunjuk oleh pimpinan setiap Badan Publik Negara yang memiliki kemampuan dalam membidangi bidang Informasi Publik.

Sebagaimana dikutip dalam UU No 14 Tahun 2008 tentang Keterbukaan Informasi Publik, (2017, p. 76) tugas dan tanggung jawab PPID:

1. Penyediaan, penyimpanan, pendokumentasian dan pengamanan informasi;

2. Pelayanan informasi sesuai dengan aturan yang berlaku;

3. Pelayanan informasi publik yang cepat,tepat dan sederhana;

4. Penetapan prosedur operasional penyebarluasan informasi publik;

5. Pengujian konsekuensi

6. Pengklarifikasian informasi atau pengubahannya;

7. Penetapan informasi yang dikecualikan yang telah habis jangka waktu pengecualiannya sebagai informasi publik yang dapat diakses; dan

8. Penetapan pertimbangan tertulis atas setiap kebijakan yang diambil untuk memenuhi hak setiap orang atas informasi publik.

\section{Definisi Publik atau Khalayak}

Jefkins (1996, p. 71) mendefinisikan khalayak atau publik adalah sekelompok orang yang berkomunikasi dengan suatu organisasi, baik secara internal maupun eksternal.

Kasali (2003, p. 10) berpendapat bahwa publik dapat dikatakan sebagai stakeholders, yakni sekumpulan orang-orang atau pihak- pihak yang memiliki kepentingan terhadap perusahaan.

Publik dapat dikelompokan berbeda-beda tergantung pada setiap organisasinya. Setiap organisasi telah menentukan publiknya masing-masing sesuai dengan kebutuhannya. Kepada publik yang berbeda itulah organisasi menjalankan komunikasi baik secara internal maupun eksternal. 


\section{Penetapan Publik}

Ada empat alasan pokok mengapa suatu organisasi perlu mengenali dan mengidentifikasi publik sebagai tujuan program komunikasinya, yakni :

1. Memilih publik yang tepat untuk dijadikan sasaran suatu program komunikasinya;

2. Menciptakan skala prioritas;

3. Memilih media yang tepat untuk menyampaikan pesan;

4. Untuk mengatur gaya bahasa dalam penyampaian pesan agar lebih mudah diterima.

\section{METODOLOGI}

Metode penelitian yang digunakan dalam penelitian ini adalah metode deskriptif kualitatif, yaitu penelitian ini akan dilakukan secara lebih mendalam dengan sejumlah pejabat yang bertanggung jawab dalam menjalankan implementasi UU No.14 Tahun 2008 Tentang Keterbukaan Informasi Publik yang dilakukan oleh PPID Kemkominfo.

Denzin dan Lincoln (dalam Pujileksono, 2015, p. 36) yang berjudul Metode Penelitian Komunikasi mengatakan bahwa penelitian kualitatif melibatkan penggunaan dan pengumpulan berbagai bahan empiris seperti studi kasus, pengalaman pribadi, riwayat hidup, wawancara yang menggambarkan suatu masalah dan maknanya.

Menurut Kountur (2007, p. 108) penelitian deskriptif adalah penelitian yang bertujuan untuk memberikan suatu gambaran atau urian atas suatu peristiwa.

Dalam penelitian ini data primer dilakukan wawancara kepada informan internal diantaranya adalah Pak Soekartono Kepala Bagian Pelayanan Indormasi di Kementrian Komunikasi dan Informasi, Pak Helmi Fajar Andrianto Kepala Subbagian media konvensional dan Pak Dedy Supriyatna D seorang supervisor yang bertugas di meja piket PPID Kementrian Komunikasi dan Informasi.

Informasi yang terkumpul dari wawancara dan observasi akan diproses melalui analisa data. Informasi yang didapat dimanfaatkan untuk mengetahui bagaimana komunikasi dalam pengimplementasian UU No.14 Tahun 2008 Tentang KIP. Penelitian ini akan bermanfaat untuk memberikan pemahaman komunikasi yang diterapkan dalam mengimplementasikan suatu kebijakan publik dan diharapkan mampu memberikan kontribusi pemikirannya dalam hal pengembangan keterbukaan informasi. 
Teknik analisis data yang digunakan dalam penelitian ini adalah teknik analisis data Model Miles and Huberman. Mengutip Miles \& Huberman (1984) (dalam Lincoln, 2009, p. 592) mengatakan bahwa analisis data terdiri atas tiga proses yang saling berkaitan, Pertama, Reduksi data (data reduction) yang diartikan seluruh potensi yang dimiliki oleh data akan disederhanakan lagi dengan sebuah mekanisme antisipatoris. Kedua, Penyajian data (data display) yang diartikan sebagai kumpulan informasi yang tersusun secara terstruktur yang memberikan kemungkinan adanya pengambilan kesimpulan dan tindakan. Kemudian tahap ketiga dalam analisis data kualitatif adalah pengambilan kesimpulan dan verifikasi data. Mengutip (Sugiyono, 2015, p. 253) mengatakan kesimpulan dalam penelitian kualitatif merupakan temuan baru yang sebelumnya tidak pernah ada. Temuan tersebut berupa deskripsi atau gambaran suatu obyek yang sebelumnya masih berupa hipotesa sehingga setelah diteliti menjadi jelas.

Teknik untuk pemeriksaan keterpercayaan dan kebenaran hasil penelitian, peneliti menggunakan triangulasi. Susan Stainback (1988) mendefinisikan tujuan dari triangulasi bukan untuk mencari kebenaran dari beberapa fenomena, tetapi lebih pada peningkatan pemahaman peneliti terhadap apa yang telah ditemukan (Sugiyono, 2015, p. 241). Dalam penelitian ini penulis memilih menggunakan teknik tringuasi sumber. Dimana pengumpulan data akan diperoleh dari tiga sumber yang berbeda. (Sugiyono, 2015). Karena peneliti memperoleh data dengan cara wawancara lebih dari satu sumber lalu menganilisis data.

\section{PEMBahaSAN}

Fokus yang digunakan dalam penelitian ini adalah empat elemen implementasi Kebijakan Publik yang digagas oleh Edward yang terdiri dari empat elemen yaitu, komunikasi, sumber daya, disposisi dan struktur birokrasi. Objek penelitian ini hanya berfokus pada implementasi Undang-Undang No.14 tentang Keterbukaan Informasi Publik yang dilakukan oleh PPID Kemkominfo, peneliti tidak membahas hal-hal diluar lingkup tersebut. Adapun Analisa data dari hasil wawancara dapat disimak dalam uraian berikut: 


\section{Komunikasi}

Menurut Edward, didalam elemen komunikasi terbagi menjadi 3 faktor penting dalam mengimplemetasikan suatu produk hukum atau kebijakan yang dikeluarkan oleh pemerintah, yaitu, pemahaman makna, konsitensi dan kejelasan.

\section{Pemahaman Keterbukaan Informasi}

Para implementor mendefinisikan transparansi sebagaimana yang tercantum dalam penjelasan UU KIP pasal 14 huruf $\mathrm{H}$ yang mengatakan bahwa transparansi adalah keterbukaan dalam melaksanakan proses pengambilan keputusan dan keterbukaan dalam mengemukakan informasi yang relevan mengenai perusahaan.

\section{Konsistensi}

PPID Kemkominfo menerapkan tujuan mengkomunikasikan impelementasi UU KIP dengan konsisten yaitu, tujuan pengimplementasian UU KIP adalah untuk menciptakan tatakelola pelayanan informasi publik yang transparan. Ketika UU KIP akan dilaksanakan, Kemkominfo mengawali langkahnya melalui enam langkah persiapan. Pertama, menunjuk PPID. Kedua, membangun sistem informasi agar bisa berkomunikasi secara optimal. Ketiga, menunjuk dan menyiapkan pejabat fungsional tertentu. Keempat, mengemas informasi dalam bentuk teks, video, data, voice dan animasi. Kelima, menyiapkan pelayanan informasi dengan menyediakan desk informasi dan website. Keenam, menyusun laporan. Setelah dipersiapkan, UU KIP tersebut kemudian diimplementasikan dan dikomunikasikan kepada publik, dengan cara mensosialisasikan UU KIP melalui pembinaan kepada para staff agar bisa menjalankan tugas dengan semaksimal mungkin, kepada masyarakat sosialisasi dilakukan melaui mengupload konten di sosial media PPID dan event.

\section{Kejelasan}

PPID Kemkominfo melakukan perintah kebijakan sesuai dengan konsistensi waktu yang dibutuhkan untuk memperoleh informasi yang di minta oleh pemohon informasi sesuai dengan aturan yang berlaku, yaitu maksimal 17 hari kerja. Hal ini di dukung oleh ketentuan yang tertulis dalam buku UU KIP (2017, p. 20) pasal 22 ayat 7 dan 8 yang menyebutkan: ''batas waktu menjawab permintaan informasi paling lambat seputuh hari kerja sejak diterimanya permintaan informasi, namun Badan Publik dapat memperpanjang waktu paling lambat tujuh hari kerja untuk menjawab permintaan informasi'”. 


\section{Sumber Daya}

Mengutip Edwards (dalam Winarno, 2012, p. 184) yang dimaksud dengan sumber daya yaitu terdiri dari sumber daya manusia dan sumber daya finansial yang mendukung kebijakan yang efektif.

Sumber daya manusia yang terdiri dari jumlah staf yang cukup dan memiliki keterampilan yang memadai, sedangkan sumber daya finansial yaitu sumber daya yang di miliki berupa dana operasional, fasilitas yang dimiliki baik secara fisik (Gedung, peralatan kerja) maupun fasilitas penunjang (training).

\section{Sumber Daya Manusia}

Jajaran PPID Kemkominfo memiliki sumber daya manusia yang ditunjuk berdasarkan kemampuan atau skill yang dimiliki oleh masing-masing implementor serta diberikan training supaya skill yang dimiliki bisa dikembangkan, sehingga mereka mengerti bagaimana menjalankan masing-masing tugasnya semaksimal mungkin, tetapi masih terdapat hambatan ketika UU KIP di implementasikan, yaitu adanya kemampuan SDM yang masih harus ditingkatkan, ketidak tersediaan data yang diminta, kurangnya koordinasi internal, sistem informasi yang belum memadai dan pengetahuan masyarakat tentang pengaduan yamg sering kali tidak sesuai dengan wewenang kominfo.

\section{Sumber Daya Finansial}

PPID Kemkominfo atau organisasi memanfaatkan sumber daya finansial atau dana operasional untuk mengembangkan lagi kemampuan yang dimiliki para staf melalui kegiatan training, workshop, dan pembinaan serta mengalokasikan dana tersebut untuk menunjang jalannya kegiatan implementasi kebijakan UU KIP.

\section{Disposisi}

Mengutip Edwards (dalam Nugroho, 2009, p. 512) menjelaskan bahwa disposisi berkenaan dengan kesediaan dan komitmen implementor untuk melaksanakan kebijakan publik. Berdasarkan hasil wawancara dengan narasumber, peneliti menarik kesimpulan bahwa ketika menjalankan tugas pengimplemntasian UU KIP para implementor harus memiliki sikap kejujuran dan demokratis. Hal ini dicerminkan dengan sikap selaku implementor, mereka bersedia dan sangat menyetujui apabila UU KIP ini diimplementasikan dengan baik dan benar. 


\section{Struktur Birokrasi}

Mengutip Edwards (dalam Nugroho, 2009, p. 512) berpendapat bahwa struktur birokrasi berkenaan dengan kesesuaian organisasi birokrasi yang menjadi penyelenggara implementasi kebijakan publik. Winarno (2012, p. 207) yang mengemukakan bahwa dengan adanya SOP dapat memberikan manfaat bagi para pelaku implementasi kebijakan publik itu sendiri atau implementor (organisasi).

Berdasarkan hasil wawancara, didapati hasil sebagai berikut:

untuk pembagian tugas implementasi itu di level kebijakan ada ppid yang bertanggung jawab membuat kebijakan dan menjawab tapi tidak secara langsung dijabat oleh plt biro humas. Pada layanan informasi dijabat oleh Kasub Pelayanan Informasi. Pada sub bagian media online diduduki oleh Kasub median online dan staffnya. Sedangkan pada regulator ada Kasubbag Media Konvensional. Dan dibagian dokumentasi diduduki oleh staff dokumentasi.

Penelitian yang membahas Implementasi Undang-Undang No 14 Tahun 2008 tentang Keterbukaan Informasi Publik oleh Pejabat Pengelola Informasi dan Dokumentasi (PPID) Kemkominfo dianalasis dengan menggunakan teori implementasi kebijakan yang dikemukakan oleh Edwards. Yang terdiri dari empat faktor, yaitu komunikasi, sumber daya, disposisi, dan struktur birokrasi. Serta menggunakan empat model Public Relations yang dikemukakan oleh Grunig\&Hunt.

Faktor pertama yaitu komunikasi adalah bagaimana cara PPID Kemkominfo meyampaikan informasi keterbukaan publik kepada masyarakat. PPID mengkomunikasikan informasi keterbukaan publik melalui enam langkah utama. Pertama, Menteri Kominfo menunjuk kepala pejabat pengelola informasi dan dokumentasi (PPID) yang dijabat oleh seorang kepala biro humas. Kedua, membangun sistem informasi. Ketiga, menyiapkan pejabat fungsional, karena didalam UU KIP disebutkan bahwa PPID dapat diperbantukan tugasnya oleh pejabat fungsional.pejabat fungsional itu sendiri terdiri dari pranata humas, arsip, dana pranata komputer. Keempat, menyediakan informasi yang dikemas ke dalam bentuk teks, video, infografis dan suara. Kelima, pelayanan informasi yaitu bisa di akses melalui front desk dan website. Keenam, membuat laporan harian, bulanan, dan tahunan. Laporan yang dibuat berupa kinerja, anggaran, dan kegiatan. Selain melakukan enam langkah diatas, PPID juga mengkomunikasikan UU KIP melalui sosialisasi di media sosial dan event. Melalui upaya tersebut, dapat dikaitkan dengan salah satu model komunikasi Grunig\&Hunt yang digunakan 
oleh peneliti. Model yang paling sesuai ialah model two-way symmetric. Pertama, dilihat dari tujuan komunikasinya, PPID sebenarnya melakukan upaya-upaya diatas untuk membangun hubungan dan pemahaman bersama apa itu keterbukaan informasi publik. Upaya tersebut direalisasikan melalui berinteraksi secara langsung saat event terselenggara, menyediakan informasi melalui website dan front desk. Kedua, dilihat dari arah komunikasi, PPID melakukan pertukaran komunikasi antara organisasinya dan publiknya, jadi PPID menganggap bahwa publik bukan hanya sekedar penerima informasi akan tetapi bisa menjadi sumber informasi bagi PPID. Ketiga, dilihat dari aspek model komunikasinya yaitu dari person to person.

Faktor kedua yaitu sumber daya adalah bagaimana kesiapan sumber daya manusia dan sumber daya finansial dalam melaksanakan UU KIP yaitu dengan mempersiapkan sumber daya manusia yang sesuai dengan bidang pekerjaannya, sedangkan dari segini sumber daya finansial dapat berupa dana operasional yang digunakan untuk memenuhi kebutuhan yang diperlukan seperti renovasi gedung dan mengadakan training bagi para implementor kebijakan UU KIP.

Faktor ketiga yaitu disposisi adalah bagaimana sikap si implementor dalam melaksanakan UU KIP. Implementor menjalankan UU KIP ini dengan sikap jujur dalam memberikan informasi, selain itu implemntor sangan menyetujui dengan adanya UU KIP ini.

Faktor keempat yaitu struktur birokrasi, yang diwujudkan dalam bentuk standart operating procedures (SOP). SOP tersebut dibuat oleh Kepala Bagian Pelayanan Informasi yang digunakan sebagai acuan atau aturan kerja bagi para implementor.

\section{E. KESIMPULAN}

Berdasarkan hasil penelitian yang dilakukan oleh penulis mengenai implementasi UU KIP yang dilakukan oleh PPID Kemkominfo dengan menggunakan metode kualitatif dan teknik pengumpulan data dengan wawancara informan sebanyak tiga orang. Maka penulis penyimpulkan bahwa implementasi UU KIP oleh PPID Kemkominfo belum berjalan dengan maksimal.

Implementasi UU No 14 tahun 2008 tentang Keterbukaan Informasi Publik oleh Pejabat Pengelola Informasi dan Dokumentasi (PPID) Kemkominfo yang menggunakan elemen-elemen implementasi dalam implementasi kebijakan public menurut Edwards yaitu Komunikasi, Sumber daya, Disposisi dan Struktur birokrasi. 
Selanjutnya peneliti menemukan beberapa hambatan yang menyebabkan implementasi UU KIP tidak berjalan dengan semaksimal mungkin, diantaranya: kemampuan atau skill implementor yang masih kurang sehingga perlu ditingkatkan lagi, adanya keterbatasan data yang diminta oleh pemohon informasi hal ini dikarenakan belum sepenuhnya data yang dimiliki oleh setiap divisi atau satuan kerja di pegang oleh PPID, kurangnya koordinasi pihak internal, dan kurangnya pemahaman masyarakat tentang pengaduan yang sering kali tidak sesuai dengan wewenang Kemkominfo.

\section{DAFTAR PUSTAKA}

Aldily, R. (2017). 1001 Amazing Public Relation Ideas. Yogyakarta: Quadrant. Jefkins, F. (1996). Public Relations . Jakarta: Penerbit Erlangga.

Kasali, R. (2003). Manajemen Public Relations . Jakarta: Pustaka Utama Grafiti.

Kementerian Komunikasi dan Informatika. (2017). Undang-Undang No 14 TAHUN 2008 tentang Keterbukaan Informasi Publik. Jakarta: Biro Humas Kominfo.

Kementerian Komunikasi dan Informatika RI . (2017). UU No 14 Tahun 2008 Tentang Keterbukaan Informasi Publik. Jakarta: Biro Hubungan Masyarakat Kemkominfo RI.

Kementerian Komunikasi dan Informatika RI. (2008). Undang-Undang No.14 Tahun 2008 Tentang Keterbukaan Informasi Publik. Jakarta: Kementerian Komunikasi dan Informatika RI.

Kementerian Komunikasi dan Informatika RI. (2017). UU No 14 Tahun 2008 Tentang Keterbukaan Informasi Publik. Jakarta: Biro Hubungan Masyarakat Kemkominfo RI.

Kementerian Komunikasi dan Informatika RI. (2017). UU No.14 Tahun 2008 Tentang Keterbukaan Informasi Publik. Jakarta: Biro Hubungan Masyarakat Kemkominfo RI.

Kountur, R. (2007). metode penelitian. jakarta: Percetakan Buana Printing.

Kriyantono, R. (2014). Teori-Teori Public Relations Prespektif Barat dan Lokal : Aplikasi Penelitian dan Praktik. Jakarta: Kencana.

mulyana, d. (2006). metodologi penelitian kualitatif . bandung: remaja rosdakarya.

Nugroho, R. (2009). Public Policy. Jakarta: PT Elex Media Komputindo.

Seketariat Jenderal dan Bidang Keahlian DPR RI. (2018, 06 21). Sejarah KIP. Retrieved from www.ppid.dpr.go.id: https://ppid.dpr.go.id/index/statik/id/13

Sugiyono. (2014). metode penelitian kuantitatif dan kualitatif. bandung: alfabeta.

Sugiyono. (2015). metode penelitian kualitatif, kuantitatif dan $R \& D$. bandung: alfabeta.

Winarno, B. (2012). Kebijakan Publik Teori Proses dan Studi Kasus . Jakarta: CAPS. 